\title{
Educative Values and Local Awareness in Folklore of Si Boko in Sungai Pisang West Sumatera
}

\author{
Vinolia ${ }^{1, *}$ \\ ${ }^{1}$ Faculty of Language and Art, Universitas Negeri Padang, Padang Indonesia. \\ *Corresponding author.Email: vinoliapadeks@ gmail.com $^{1}$
}

\begin{abstract}
This article contains educational values and local wisdom in a folklore in one of the areas in the city of Padang, namely the folklore of Si Boko. This folklore is the property or wealth of the community in Sungai Pisang Village, Bungus Teluk Kabung District, Padang. In order for this folklore to be preserved, documentation and archiving are required. One of the documentation is the implementation of this research. Furthermore, this study is more specifically aimed at describing the educational values and local wisdom contained in the story. This research uses a qualitative approach with descriptive methods. The object of this research is the folklore of Si Boko in Sungai Pisang Village, which was told directly by one of the community leaders in the area. Data collection was done by recording and recording. The data of this research is the folklore text of Si Boko in Sungai Pisang Village which is obtained from the transcription (over the script). After the data is obtained in accordance with the research method, it is followed by describing and interpreting the research results. Based on the results of data analysis, research results can be obtained in the form of educational values and local wisdom in the folklore of Si Boko. These values are expressed in the form of phrases and sentences. The educational value found is reflected in the local wisdom contained in the folklore, the values found in the form of hard work, never giving up, love for the country, independence, courage, compassion and etc.
\end{abstract}

Keywords: folklore, (folklore), si Boko, educational values, local wisdom.

\begin{abstract}
1. INTRODUCTION
Folklore or oral literature is part of a tradition that develops in community groups by using language as the main medium. This oral folklore appeared and developed in society earlier than written literature. In everyday life, this type of literature is usually spoken by a mother to her child, a storyteller to listeners, teachers to students or among members of the community to maintain the continuity of this oral literature, the local people passed it down from generation to generation.

Oral literature is also referred to as folk literature because it appears and develops in the midst of people's lives. Hutomo [1] said that oral literature is literature that includes literary expressions of the citizens of a culture that is spread and passed down from generation to generation orally (word of mouth). This oral literature is shared, listened to and lived together on certain events, with specific aims and objectives as well. These events, among others, relate to the origin of the naming of an area, wedding ceremonies, rice planting
\end{abstract}

and reaping ceremonies, birth of babies and ceremonies with magical purposes.

Oral literature is very popular with the public and is usually listened to together because it contains the ideas, thoughts, teachings and hopes of the community. The atmosphere of togetherness that results from oral literature has a positive impact on strengthening the inner bonds between members of the community. in this context, it can be seen that oral literature also has a social and individual function. Thus, it can be said that the waning of oral literary traditions in society is an indication of the waning of social ties between them.

Oral literature has the potential and role as cultural assets. Oral literature can be used as a capital for appreciation. With oral literature, people can find out the history, experiences, views of life, customs, ideals and various other activities that exist around literary life. in that sense, literary works of art actually implied the realities of society. This means that the presence of writers plays a role and takes part as a mouthpiece of society to explain ideas, aspirations or 
wishes. the maintenance of the development of oral literature in the Sungai Pisang area is closely related to the maintenance of culture as the identity of a community group. There is a tendency for parents in Sungai Pisang to be reluctant to tell the si Boko folklore to the next generation, so that many young people in this area do not really know the storyline of Si Boko and some of them don't even know the story at all and only hear the title. Therefore, it is important to conduct this research as a form of documenting folklore so that it does not become extinct. In addition, the folklore of Si Boko is related to the history of naming small islands around the Sungai Pisang area, there are at least three small islands whose names are believed by the local community as part of the Si Boko storyline, namely Pasumpahan Island, setan Island and Sikuai Island. It is important to know the origin of the naming of the island to the next generation of Sungai Pisang so that it can tell it back to the next generation or to the outside community considering that these three small islands are one of the leading tourist destinations of the Padang city government which are quite crowdedtraveler. In addition to a form of preservation, in the folklore of Si Boko, it is necessary to explore educational values and local wisdom so that future generations can emulate them. In folklore, there are generally educational values including (1) values (moral / character), (2) faith and piety, (3) honesty, (4) toughness, (5) politeness, (6) intelligence, (7) Concern, (8) justice, and others. These values are held and guided by the community in solving life problems and social problems. In general, folklore contains truth values that are educational. It can be seen in various figures and characters, or in its complete form as a human.In the end, whether it is acknowledged or not, literary works have a position that cannot be underestimated in maintaining or recording a culture, or vice versa in forming a new culture, without losing its positive educational values.

Before analyzing an educational value contained in a folk tale of Si Boko, here is a little description of the knowledge of educational values. Value is something that is valuable, quality, shows quality, and is useful for humans. something is valuable or useful for human life. The characteristics of value according to Bambang Daroeso [2] are as follows: First, value is an abstract reality and exists in human life. Abstract values cannot be sensed. The only thing that can be observed is that object of value. For example, people who have honesty. Honesty is a value but humans cannot sense honesty. What we can observe is the object or result of that honesty. Second, values have a normative nature, meaning that values contain hopes, ideals, and a necessity so that values have ideal characteristics (das sollen). Values are manifested in the form of norms as the basis for human action. For example, the value of justice. Everyone hopes and gets and behaves that reflect the value of justice. Third, values function as a motivator and humans are value supporters. humans act based on and driven by the values they believe in. For example, the value of piety. The existence of this value makes everyone motivated to be able to achieve the degree of piety. Meanwhile, according to the $\mathrm{KBBI}$, education is the process of changing the attitudes and behavior of a person or group of people in an effort to mature humans through teaching and training efforts; educational processes, methods, and actions. so educational value can be interpreted about the good and bad behavior of someone that we can take and follow in order to create a good social life order.

In addition to educational values, in this folklore there is also local wisdom that reflects educational values. In the Indonesian English Dictionary by John M. Echols and Hassan Shadily [3], local means local, while wisdom is the same as wisdom. In general, local wisdom can be understood as local ideas that are wise, full of wisdom, of good value, which are embedded and followed by members of the community. In the discipline of anthropology, the term local genius is known.

According to Indrayuda [4] local wisdom is the values or behavior of local communities in interacting wisely with the environment in which they live. Therefore, local wisdom is not the same at different places and times and different race, tribes and region [5]. This difference is caused by natural challenges and different needs of life, so that his experience in fulfilling his life needs has led to various knowledge systems related to both the environment and the social. As a form of human behavior, local wisdom is not a static thing but changes over time, depending on the existing sociocultural structures and ties in society.

\section{Local Knowledge dimension}

1. Dimensions of local knowledge: Local knowledge related to the environment. Knowledge of climate change and cycles (rainy, dry), types of flora and fauna and their behavior; geographical, demographic and sociographic conditions. The ability to adapt to the environment is part of local knowledge. (Character values: Toughness, intelligence).

2. Dimensions of local values: The rules of living together among residents, are mutually agreed upon and obeyed. Values that regulate the relationship between man and God, man and man, man and nature. Past, present and future values are included in the dimensions of local values. (Character values: Faith and piety, honesty, politeness, caring).

3. Dimensions of local skills: Local skills that are used for the ability to survive (survival). Hunting, gathering, farming, home industry and others are included in local skills. (Character value: Toughness and hard work)

4. Dimensions of local resources: Utilization of local natural resources such as how to protect, care for, and utilize water sources, forests, land and settlements. (Character values: intelligence, politeness).

\section{METHOD}

Based on theoretical references, this study uses a qualitative descriptive approach. An approach that presupposes data in research in the form of words, sentences and paragraphs that are in accordance with the object of research [6]. This research is a research that produces descriptive data in the form of written words. The source of the research data is the folklore text Si Boko from the recorded interviews then transcribed (transcribed) then transliterated (translation) 
from the local language of Minangkabau into Indonesian language. The interviewer was a resident of Sungai Pisang named Hasan Leni Dt Rajo Lenggang is 67 years old. He was born and raised in the Sungai Pisang area to parents who are both natives of Sungai Pisang. In the village, Hasan Leni Dt. Rajo Lenggang serves as chairman of the Musyawarah Council (Bamus) for Sungai Pisang Village. Beside that he also holds the title Niniak Mamak (community leader) in the Sungai Pisang. The story of Si Boko was the first time he heard from his father (late) when he was 17 years old. At that time, Hasan Leni's father Dt. Rajo Lenggang served as Panghulu kampuang (village leader).
The legend of Si Boko grows and lives in the hearts of the people of Sungai Pisang village. Most people believe that the legend really exists. The community's belief in the legend is proven by the behavior and habits of the local community. In Sungai Pisang village, mothers often mention Si Boko's name when they see the behavior of their children who are wayward and not in accordance with the norm. "Ka maniru si Boko waang, cubolah, buliah dikutuak jadi batu," (Do you want to imitate si Boko? try to be cursed to stone later), one a Sungai Pisang woman said when the researcher visited the village. From research conducted on the text of the Boko folklore found several words, phrases and sentences that contain educational values and local wisdom. Look at the table below.

\section{RESULT AND DISCUSSION}

Table 1. Identification of educational values and local wisdom

\begin{tabular}{|c|c|c|c|}
\hline No. & & $\begin{array}{l}\text { Education } \\
\text { Values }\end{array}$ & $\begin{array}{l}\text { Local } \\
\text { Wisdom } \\
\text { Values }\end{array}$ \\
\hline 1. & Boko and her mother farm there. & $\sqrt{ }$ & $\sqrt{ }$ \\
\hline 2. & $\begin{array}{l}\text { After a long period of farming there, Si Boko's desire to go } \\
\text { to Baru (the village) grew to go overseas. }\end{array}$ & $\sqrt{ }$ & $\sqrt{ }$ \\
\hline 3. & $\begin{array}{l}\text { After thirty years passed, Si Boko returned to his hometown, } \\
\text { Sungai Pisang. }\end{array}$ & $\sqrt{ }$ & $\sqrt{ }$ \\
\hline 4. & Words, Phrases, Sentences & $\sqrt{ }$ & $\sqrt{ }$ \\
\hline 5. & $\begin{array}{l}\text { Boko: "It is impossible for me to be your child, you are old, } \\
\text { my mother is not like you, she is young, not like you, your } \\
\text { eyes so dirty }\end{array}$ & $\sqrt{ }$ & - \\
\hline 6. & $\begin{array}{l}\text { Amak: "I am your mother, of course it is old because we } \\
\text { haven't seen each other for a long time" }\end{array}$ & $\sqrt{ }$ & - \\
\hline 7. & $\begin{array}{l}\text { "You are not my mother, expel ..." (Boko ordered his men to } \\
\text { expel his mother). Then Boko's mother who was on the ship } \\
\text { was driven under the ship by Boko). }\end{array}$ & $\sqrt{ }$ & - \\
\hline 8. & $\begin{array}{l}\text { If it is true I am not your mother Boko, be your stone, capsize } \\
\text { your ship ". }\end{array}$ & $\sqrt{ }$ & - \\
\hline 9. & $\begin{array}{l}\text { after his ax turned to stone, then Boko confessed. "Indeed } \\
\text { you are my mother". But it's useless, the oath has been } \\
\text { pronounced so that everything is ruined. }\end{array}$ & $\sqrt{ }$ & - \\
\hline 10. & $\begin{array}{l}\text { After the ship and its contents capsized, Boko's mother went } \\
\text { to an island. On the island, he felt that he was possessed by } \\
\text { the devil. (now called pulau setan }\end{array}$ & $\sqrt{ }$ & - \\
\hline
\end{tabular}

Symbol description: $\sqrt{ }=$ contains value

$-=$ does not contain value

\section{Discussion between sentences in the text of the Boko} folklore

The sentence "Boko and her mother farm there" contains an educational value of working hard. Farming is an activity of growing plants. The educational value in farming is hard work, rural people are generally hardworking and like to work together. Besides that, the sentence above also contains local wisdom values. The value of local wisdom is farming, farming is a characteristic of rural communities by farming them to meet their daily needs.
In the sentence "After a long period of farming there grew the desire of Si Boko to go to new (village) to go wanderers" contains educational values, courage and an attitude of independence. Merantau is an activity of visiting other places that have not been visited for a long time with the aim of trying one's luck and changing one's life for the better, by wandering people can train one's courage and independence. In addition, wandering contains the value of local wisdom. Merantau is a characteristic of the Minangkabau people (West Sumatra). Since childhood, 
men in Minangkabau are trained to migrate, one of which is by sleeping in Surau.

In the sentence "After thirty years have passed, Boko will return to his hometown, Sungai Pisang" contains the educational value of loving the country. The sentence contains Boko's love for his hometown. Minangkabau people really love their hometown, wherever they migrate, one day they will definitely come home.

In the sentence "It is said by the villagers who are fishing or looking for fish to Mrs. Si Boko that Boko has returned home" contains the educational value of working hard. By doing fishing activities or fishing in the sea, fishermen can fulfill their daily needs. besides going to sea reflects a brave and unyielding attitude. This sentence also contains local wisdom, fishing is an activity of catching fish using nets, this is a characteristic of coastal communities including coastal communities in Minangkabau.

Boko: "It is impossible for me to be your child, Mother is old, my mother is not like you, she is still young, not like you, your eyes its so dirty".

The passage of the conversation shows that Boko has a bad character because he likes to scold. in everyday life we should promote affection for fellow humans and not judge someone from their physical appearance.

Amak: "I am your mother, of course I am old because we haven't seen each other for a long time." This piece of conversation shows that Boko's mother has an unyielding attitude, she tries to convince $\mathrm{Si}$ Boko that she is her mother. "You are not my mother, expel ..." (Boko ordered his men to expel his mother). Then Boko's mother who was on the ship was driven under the ship by Boko). The conversation fragment shows that Boko has a rude attitude. In everyday life we are required to use gentle language and not to hurt someone's heart. "If it is true that I am not your mother, Boko, be you a stone, capsize your ship". This sentence shows the wrath of Si Boko's mother for not being recognized as Boko's parent. the sentence symbolizes heartache. In everyday life we should not indulge in anger, because anger will lead to badness, both for ourselves and for others.

Only after the ship turned to stone did Boko confess. "Indeed you are my mother". However, it is useless, the oath has been spoken so that everything is ruined. This sentence shows Boko's regret, he regrets his actions for not recognizing his biological mother. The sentence contains moral values that we must think before acting, careless actions will harm ourselves.

"After the ship and its contents capsized, Boko's mother went to an island. On the island, he felt that he was possessed by a demon (now called Pulau Setan)". This sentence reflects a mother's regret for cussing her child. in life we must consider the merits of our words so as not to cause problems in the future.

\section{CONCLUSION}

Educational values in the form of noble advice or wisdom values or local wisdom contained in folklore have quite a variety of social functions, including as a projection system, as a means of legalizing social institutions and institutions, as a means of children's education, and as a means of coercing and monitoring community norms so that they are always obeyed. folklore has the potential and role of cultural wealth. Folklore can be used as a capital of appreciation. with folklore, people can find out the history, experiences, views of life, customs, ideals and various other activities that exist around the literary life. In that sense, literary creations actually implied the realities that existed in society.

Furthermore, Minangkabau folklore, like spoken language in general, is also a means of communication, especially in terms of concrete social control to criticize a person or group who has violated the norms of society. Based on this conclusion, it is suggested that universities, local governments, and other government agencies need to promote research, exploration, and formulation of traditional values that live and grow in society. This is important because traditional values are able to function at some point as arguments in science. universities, local governments, and other government agencies, as well as society in general not to ignore and despise the folk tales that live and grow in society. Every society, no matter how modern the society is, actually needs a handle on life in the form of beliefs and wisdom values

\section{REFERENCES}

[1] S. S. Hutomo, Mutiara yang terlupakan: Pengantar studi sastra lisan. Surabaya: Himpunan Sarjana Kesusastraan Indonesia, Komisariat Jawa Timur, 1991.

[2] B. Daroeso, Dasar dan konsep pendidikan moral Pancasila. Aneka Ilmu, 1986.

[3] J. M. Echols and H. Sadily, Kamus InggrisIndonesia: An English-Indonesian Dictionary. Jakarta: Gramedia, 1975.

[4] I. Indrayuda, "The existence of local wisdom value through Minangkabau dance creation representation in present time," Harmon. J. Arts Res. Educ., vol. 16, no. 2, p. 143, 2017.

[5] Asmawati, Y. Hayati, I. G. D. Pertiwi, and M. Adek, "“Birds of a Feather Flock Together': The Comparison Between Two Folklores Bawang Merah Bawang Putih and Putri Arabella," in Proceedings of the 3rd International Conference on Language, Literature, Culture, and Education (ICOLLITE 2019), 2020.

[6] M. B. Miles and A. M. Huberman, Qualitative Data Analysis: An Expanded Sourcebook, 2nd ed. Thousand Oaks, CA: SAGE Publications, 1994. 